\title{
Review of 2004
}

\author{
The Editors (JEFFREY BROWN, STEVEN HABERMAN, MOSHE MILEVSKY \\ and MIKE ORSZAG) and the Managing Editor (ANDRE LABOUL)
}

As we begin the fourth volume of the Journal of Pension Economics and Finance, we are pleased that the Journal has begun to achieve important parts of its mission of being an influential contributor to the debate on pension provision. The Journal is now in about half of the top US academic libraries and is also indexed by EconLit and AgeLine. Pension and social security issues continue to be on top of the policy and research agenda in most major countries. As the first and only academic journal focusing entirely on pension economics and finance, the Journal of Pension Economics and Finance has been in a unique position to contribute to the public debate.

The Journal continues to benefit from a high overall quality of submissions and referee reports prepared by members of the research community. The Journal received 58 new submissions in the calendar year 2004, a $26 \%$ increase over the previous year. We also found overall that the quality of submissions in 2004 had increased over 2003. During the year, we accepted 17 papers and rejected or made a revise/resubmit decision on 34 . There were 18 papers in process at the end of 2004.

The editors have been pleased that in a majority of cases we have been able to respond quite expeditiously to submissions. We double blind review our paper submissions and try to use at least 2 referees. A large part of our success is due to the efficiency of the editorial office which is run by Nina Paklina at the OECD as well as extraordinary cooperation from a majority of referees. The high quality of the majority of reviews and efforts of the reviewers is something we appreciate greatly as editors. During the second half of the year, it became clear that the administrative burden of all the editors considering each paper was becoming too high in light of the increase in submissions. We therefore set up a system whereby each incoming paper is assigned to and managed by one of the four co-editors. While co-editors can reject papers without consulting the other co-editors, acceptance or revise requests are still cleared by all the editors.

We continue to benefit from the excellent subscription base because of our cooperation with the OECD and its International Network of Pension Regulators and Supervisors (INPRS). As a result, all the major regulators and supervisors in the 65 member countries of the INPRS as well as 12 international organisations have institution-wide electronic access to the Journal as well as hardcopy subscriptions. Supervisors around the world have formed a new association called the International Organisation of Pension Supervisors (IOPS) which has a cooperative agreement with the OECD. Going forward, it is our expectation that the Journal will be published in 
association with this new organisation as well as the OECD. During the past year we have made substantial progress in building our subscription base with US libraries but there still much to be done. If you are a faculty member or student at an academic institution, we therefore urge you to check whether your library subscribes and to encourage them to subscribe if they are not already doing so. We are also accessible on the web at www.pensions-journal.org

Pensions policy is an important part of the Journal's mission and this is reflected both in our association with INPRS, IOPS and the OECD and the articles which we publish. We are accordingly pleased that one of the co-editors Jeff Brown has been named by President Bush to the Social Security Advisory Board. During Volume 3, we also published a special issue on US hybrid pensions, which presented issues \& policy pieces on issues relevant for US hybrid pensions. This issue was edited by Jeff Brown, Mike Orszag and Syl Schieber.

In addition to research and issues \& policy pieces, one of the successes of the Journal in Volume 3 has been the Book Review section edited by Olivia Mitchell, director of the Pension Research Council at the Wharton School, University of Pennsylvania. In highlighting key book-length contributions on pensions, the Review section has enhanced the value of the Journal by augmenting the original research papers and policy papers in the Journal with summaries of research done elsewhere.

We also would like to take this opportunity to re-emphasize the discussion of the coverage of the journal we raised in the introduction to Volume 1. Examples of subjects we identified which fit within the remit of the journal are:

- Pension Finance. How should pensions be financed? How affordable are current pensions and social security arrangements?

- Benefit Design. What are the optimal structures of pension and related benefits? What are the incentive effects of different means of provision of retirement income?

- Valuation. How should corporate and social security pension liabilities be valued?

- Risk Analysis. How much risk for individuals and corporations is there in different forms of pension plans?

- Investment. What is the optimal asset allocation for private pension funds? What are the best ways for pension funds to match assets and liabilities?

- Pensions \& Labour Markets. What are the labour market effects of different public and private pension arrangements?

- Private Pension Distribution \& Delivery. What is the most efficient way to ensure adequate, low cost distribution of private pensions?

- Regulation. What are the effects of different forms of regulation of private pension plans?

- Political Economy. How do political economy considerations affect the possibilities of pension reform?

- Taxation. What are the effects of different tax arrangements on private pensions?

- Governance. What are the best governance mechanisms for pension funds? 
There have been important developments in pensions over the past year or so:

- The US social security debate has highlighted issues connected with individual accounts.

- The introduction of international accounting standards around the world is providing enhanced transparency on corporate pension liabilities.

- The UK has introduced a pension guarantee fund, along the lines of the US Pension Benefit Guarantee Corporation (PBGC)

We fully expect to see these developments reflected both in original research articles in the journal as well as in our issues \& policy pieces. We therefore welcome submissions of papers in these areas.

Finally, we welcome your feedback and ideas for improving the Journal in its mission as serving as a forum for the international debate on pension provision. With your help, we will be more likely to achieve what we strive to become - one of the most influential resources on pensions in the world. 